\title{
SEMI-MARKOV MODELS OF SAFETY OF THE RENEWAL SYSTEMS OPERATION
}

\section{SEMI-MARKOWSKIE MODELE NIEZAWODNOŚCI I BEZPIECZEŃSTWA SYSTEMÓW ODNAWIALNYCH}

\author{
Grabski Franciszek ${ }^{1}$, Jaźwiński Jerzy ${ }^{2}$ \\ (1) Akademia Marynarki Wojennej w Gdyni. \\ (2) Air Force Institute of Technology \\ Instytut Techniczny Wojsk Lotniczych \\ 01-494 Warszawa ul. Księcia Bolesława 6 \\ e-mail: finmg@univ.gda.pl jjur@wp.pl
}

\begin{abstract}
Usually, the renewal systems are mathematically described by the alternating renewal process, which is special case of the semi-Markov process. It allows us to find the basic reliability characteristics like the renewal function, the operational availability of the system and many other. Many papers are devoted to that problem. Very often the operation of the system is perturbed by the danger events. The operation process of the system is broken or stopped. In that case we can say that the unsafety event occurred. Semi-Markov model of the safety of operation is constructed in this paper. The safety characteristics of the system operation are calculated by using the properties of the semi-Markov processes.
\end{abstract}

Keywords: reliability models, safety models, systems safety

Streszczenie: Dwustanowe systemy odnawialne modelowane są alternatywnym (alternującym) procesem odnowy, który jest szczególnym przypadkiem procesu semimarkowskiego. Pozwala to wyznaczyć podstawowe wskaźniki niezawodności systemu, takie jak: funkcja odnowy, gęstość odnowy, gotowość systemu, gotowość operacyjna systemu, staż systemu. W licznych publikacjach problem ten został szeroko omówiony. W realnie istniejących systemach stanom pracy, jak również stanom odnowy systemu towarzyszą zdarzenia powodujące przerwy w procesie eksploatacji lub zakończenie tego procesu. Często następuje zniszczenie systemu lub uszkodzenie uniemożliwiające jego dalsze użytkowanie lub odnowę. W takiej sytuacji powiemy, że wystąpiła zawodność bezpieczeństwa systemu. Wyznaczone wskaźniki niezawodności systemu ulegają modyfikacji. W pracy podano algorytmy wyznaczenia wskaźników niezawodności i bezpieczeństwa takiego systemu, wykorzystując do tego celu procesy semi-markowskie.

Słowa kluczowe: modele niezawodności, modele bezpieczeństwa, bezpieczeństwo systemów 


\section{SEMI-MARKOV MODELS OF SAFETY OF THE RENEWAL SYSTEMS OPERATION}

\section{Description of the problem and assumptions}

In many real cases the duration of functioning periods and repair or replacement periods of a system (object) we can treat as the random variables. The operation of the system we can describe by the two states stochastic process. In practice, the unsafety event (perturbation of safety) can occur in functioning period as well as in repair period of the system. This event can stop ore break the operation process. Our aim is to construct the stochastic model describing the process of operation with the perturbations of the system safety. This model allow us to obtain the safety characteristics of the system .

We assume that duration of the functioning periods are the independent copies of the positive random variable $\xi$ with $c d f$ (cumulative density function) $F_{\xi}(\cdot)$; the duration of renewal periods ( repair or replacement periods ) are the independent copies of the positive random variable $\eta$ with $c d f F_{\eta}(\cdot)$.

We introduce the following states of the system:

$$
\begin{aligned}
& S_{p} \leftrightarrow 1-\quad \text { work of the system } \\
& S_{o} \leftrightarrow 2 \quad-\quad \text { renewal of the system } \\
& S_{B} \leftrightarrow 3 \quad-\quad \text { damage (failure) of the system }
\end{aligned}
$$

We will consider three models of safety for the mentioned above stochastic model of operation.

1.The system during functioning period can damage. The time to this event (time to failure) of a functioning system is a positive random variable $\varsigma$ with a probability density function $f_{s}(\cdot)$. The failure causes stopping of the operation process. Possible states changes of the system are shown in figure 1. 


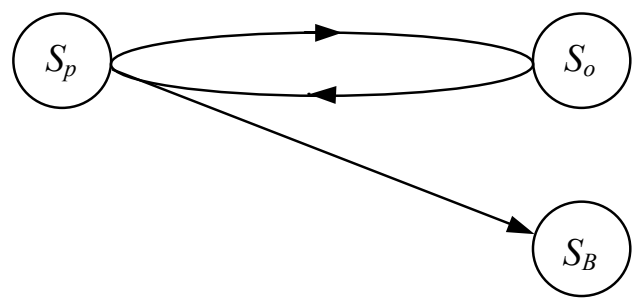

Fig. 1. A flow graph of the operation with a safety perturbation of the working states

2.The system during renewal periods can fail. The time to failure of a repairing system is a positive random variable $\gamma$ with a probability density function $f_{\gamma}(\cdot)$. The failure causes stopping of the operation process. Possible states changes of the system in this case are shown in figure 2 .

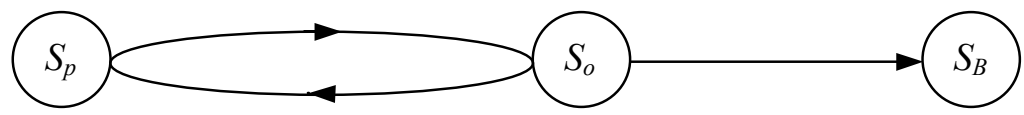

Fig. 2. A flow graph of the operation with a safety perturbation in the renewal states

3.The system during both functioning and renewal periods can damage. The time to failure of a functioning system is a positive random variable $\varsigma$ with a probability density function $f_{c}(\cdot)$, time to a failure of a repairing system is a positive random variable $\gamma$ with a probability density function $f_{\gamma}(\cdot)$. The failure causes stopping of the operation process. Possible states changes of the system are shown in figure 3.

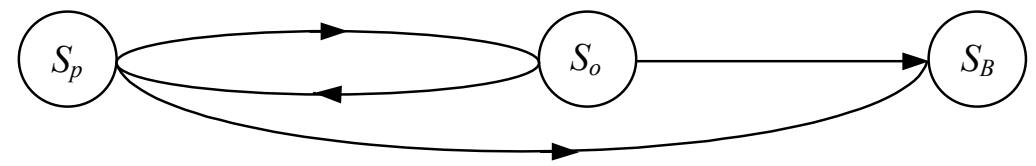

Fig. 3. A flow graph of the operation with a safety perturbation in the working and renewal states

We assume that the all random variables are mutually independent.

\section{Model}

To obtain the safety and reliability characteristics of the system $\mathrm{w}$ have to construct a stochastic model describing an operation process with a 
perturbation of the system safety. Under fixed assumptions the only model is semi-Markov process $\{X(t): t \geq 0\}$ with a state space $S=\{1,2,3\} \equiv\left\{S_{p}, S_{o}, S_{B}\right\}$ To obtain a semi-Markov model we have to define all nonnegative elements of a semi- Markov kernel

$$
\begin{gathered}
\mathbf{Q}(t)=\left[Q_{i j}(t): i, j \in S\right] \\
Q_{i j}(t)=P\left\{X\left(\tau_{n+1}\right)=j, \tau_{n+1}-\tau_{n} \leq t \mid X\left(\tau_{n}\right)=i\right\}
\end{gathered}
$$

We will construct most general model corresponding to a graph shown in figure 3.

$$
\mathbf{Q}(t)=\left[\begin{array}{ccc}
0 & Q_{12}(t) & Q_{13}(t) \\
Q_{21}(t) & 0 & Q_{23}(t) \\
0 & 0 & Q_{33}(t)
\end{array}\right],
$$

From assumption we obtain

$$
\begin{gathered}
Q_{12}(t)=P\{\xi \leq t, \varsigma>\xi\}=\int_{0}^{t}\left[1-F_{\zeta}(x)\right] d F_{\xi}(x), \\
Q_{13}(t)=P\{\zeta \leq t, \varsigma<\xi\}=\int_{0}^{t}\left[1-F_{\xi}(x)\right] d F_{\zeta}(x), \\
Q_{21}(t)=P\{\eta \leq t, \gamma>\eta\}=\int_{0}^{t}\left[1-F_{\gamma}(x)\right] d F_{\eta}(x), \\
Q_{23}(t)=P\{\gamma \leq t, \gamma<\eta\}=\int_{0}^{t}\left[1-F_{\eta}(x)\right] d F_{\gamma}(x), \\
Q_{33}(t)=H(t) .
\end{gathered}
$$

By substitution

$$
F_{\gamma}(x)=\left\{\begin{array}{lll}
0 & \text { for } & \mathrm{x}<\infty \\
1 & \text { for } & \mathrm{x}=\infty
\end{array}\right.
$$

we get a model corresponding to a graph that is shown in figure 1 . Since

$$
\begin{gathered}
Q_{12}(t)=\int_{0}^{t}\left[1-F_{\zeta}(x)\right] d F_{\xi}(x), \\
Q_{13}(t)=\int_{0}^{t}\left[1-F_{\xi}(x)\right] d F_{\zeta}(x), \\
Q_{21}(t)=F_{\eta}(t), \\
Q_{23}(t)=0,
\end{gathered}
$$

A model corresponding to a graph that is shown in figure 2, we obtain by substitution 


$$
F_{\varsigma}(x)=\left\{\begin{array}{lll}
0 & \text { for } & \mathrm{x}<\infty \\
1 & \text { for } & \mathrm{x}=\infty
\end{array}\right.
$$

In this case elements of the semi-Markov kernel are

$$
\begin{gathered}
Q_{12}(t)=F_{\xi}(t), \\
Q_{13}(t)=0, \\
Q_{21}(t)=P\{\eta \leq t, \gamma>\eta\}=\int_{0}^{t}\left[1-F_{\gamma}(x)\right] d F_{\eta}(x), \\
Q_{23}(t)=P\{\gamma \leq t, \gamma<\eta\}=\int_{0}^{t}\left[1-F_{\eta}(x)\right] d F_{\gamma}(x) .
\end{gathered}
$$

\section{Safety and reliability characteristics}

From definition of the semi-Markov process [ ] it follows that in instants of the states changes the sequence $\left\{X\left(\tau_{n}\right): n=0,1,2, \ldots\right\}$ is a Markov chain with the transition probabilities matrix

$$
\mathbf{P}=\left[p_{i j}: i, j \in S\right], \quad p_{i j}=P\left\{X\left(\tau_{n+1}\right)=j \mid X\left(\tau_{n}\right)=i\right\}=\lim _{t \rightarrow \infty} Q_{i j}(t)
$$

The sequence $\left\{X\left(\tau_{n}\right): n=0,1,2, \ldots\right\}$ is called an embedded Markov chain in a semi-Markov process $\{X(t): t \geq 0\}$. In our general model

$$
\mathbf{P}=\left[\begin{array}{ccc}
0 & p_{12} & p_{13} \\
p_{21} & 0 & p_{23} \\
0 & 0 & 1
\end{array}\right],
$$

where

$$
\begin{gathered}
p_{12}=P\{\varsigma>\xi\}=\int_{0}^{\infty}\left[1-F_{\varsigma}(x)\right] d F_{\xi}(x), \\
p_{13}=P\{\varsigma<\xi\}=\int_{0}^{\infty}\left[1-F_{\xi}(x)\right] d F_{\zeta}(x)=1-p_{12}, \\
p_{21}=P\{\gamma>\eta\}=\int_{0}^{\infty}\left[1-F_{\gamma}(x)\right] d F_{\eta}(x), \\
p_{23}(t)=P\{\gamma<\eta\}=\int_{0}^{\infty}\left[1-F_{\eta}(x)\right] d F_{\gamma}(x)=1-p_{21},
\end{gathered}
$$

Trajectories of that process keeps the constant values on the half-intervals $\left[\tau_{n}, \tau_{n+1}\right)$ and they are the right-continuous functions.

The function

$$
F_{i j}(t)=P\left\{\tau_{n+1}-\tau_{n} \leq t \mid X\left(\tau_{n}\right)=i, X\left(\tau_{n+1}\right)=j\right\}=\frac{Q_{i j}(t)}{p_{i j}}
$$


is a cumulative probability distribution of a random variable $T_{i j}$ that is called holding time of a state $i$, if the next state will be $j$. From (11) we have

$$
Q_{i j}(t)=p_{i j} F_{i j}(t)
$$

The function

$$
G_{i}(t)=P\left\{\tau_{n+1}-\tau_{n} \leq t \mid X\left(\tau_{n}\right)=i\right\}=\sum_{j \in S} Q_{i j}(t)
$$

is a cumulative probability distribution of a random variable $T_{i}$ that is called waiting time of the state $i$. The waiting time $T_{i}$ means the time being spent in state $i$ when we do not know the successor state. In our model

$$
G_{1}(t)=Q_{12}(t)+Q_{13}(t), \quad G_{2}(t)=Q_{21}(t)+Q_{23}(t), \quad G_{3}(t)=Q_{33}(t)
$$

Very important characteristic of semi-Markov process is the first passage time from the state $i$ to the states subset $A$.

The random variable

$$
\Theta_{A}=\tau_{\Delta_{A}},
$$

where

$$
\Delta_{A}=\min \left\{n \in N: X\left(\tau_{n}\right) \in A\right\},
$$

denotes the time of first arrival of semi-Markov process, at the set of states $A$.

The function

$$
\Phi_{i A}(t)=P\left\{\Theta_{A} \leq t \mid X(0)=i\right\}
$$

is the cumulative distribution of the random variable $\Theta_{i A}$ that denotes the first passage time from the state $i$ to the states subset $A$.

\section{Theorem [2]}

For the regular semi-Markov processes such that,

$$
f_{i A}=P\left\{\Delta_{A}<\infty \mid X(0)=i\right\}=1, \quad i \in A^{\prime},
$$

the distributions $\Phi_{i A}(t), i \in A^{\prime}$ are proper and they are the unique solutions of the system of equations

$$
\Phi_{i A}(t)=\sum_{j \in A} Q_{i j}(t)+\sum_{k \in S} \int_{0}^{t} \Phi_{k A}(t-x) d Q_{i k}(x), i \in A^{\prime}
$$

Applying Laplace-Stielties transformation we obtain the system of linear equations 
$\widetilde{\phi}_{i A}(s)=\sum_{j \in A} \widetilde{q}_{i j}(s)+\sum_{k \in A^{\prime}} \widetilde{\phi}_{k A}(s) \widetilde{q}_{i k}(s), i \in A^{\prime}$

with unknown transforms

$$
\widetilde{\phi}_{i A}(s)=\int_{0}^{\infty} e^{-s t} d \Phi_{i A}(t) .
$$

In matrix form we have equation

$$
\left(I-\widetilde{\mathbf{q}}_{A^{\prime}}(s)\right) \widetilde{\boldsymbol{\varphi}}_{A^{\prime}}(s)=\widetilde{\mathbf{b}}(s),
$$

where

$$
\begin{gathered}
\mathbf{I}=\left[\delta_{i j}: i, j \in A^{\prime}\right], \quad \widetilde{\mathbf{q}}_{A^{\prime}}(s)=\left[\widetilde{q}_{i j}(s): i, j \in A\right] \\
\widetilde{q}_{i j}(s)=\int_{0}^{\infty} e^{-s t} d Q_{i j}(t)
\end{gathered}
$$

are the square matrices and

$$
\widetilde{\boldsymbol{\varphi}}_{A^{\prime}}(s)=\left[\widetilde{\varphi}_{i A}(s): i \in A^{\prime}\right]^{T}, \quad \widetilde{\mathbf{b}}(s)=\left[\sum_{j \in A} \widetilde{q}_{i j}(s): i \in A^{\prime}\right]^{T}
$$

are the one column matrices of transforms.

In considered model we have $A^{\prime}=\{1,2\}, A=\{3\}$,

$$
\mathbf{I}=\left[\begin{array}{ll}
1 & 0 \\
0 & 1
\end{array}\right], \quad \widetilde{\mathbf{q}}_{A^{\prime}}(s)=\left[\begin{array}{cc}
0 & \widetilde{q}_{12}(s) \\
\widetilde{q}_{21}(s) & 0
\end{array}\right], \quad \widetilde{\varphi}_{A^{\prime}}(s)=\left[\begin{array}{l}
\widetilde{\varphi}_{13}(s) \\
\widetilde{\varphi}_{23}(s)
\end{array}\right], \quad \widetilde{\mathbf{b}}(s)=\left[\begin{array}{c}
\widetilde{q}_{13}(s) \\
\widetilde{q}_{23}(s)
\end{array}\right] .
$$

In this case, the solution of the equation (32) is

$$
\begin{gathered}
\widetilde{\varphi}_{13}(s)=\frac{\widetilde{q}_{13}(s)+\widetilde{q}_{12}(s) \widetilde{q}_{23}(s)}{1-\widetilde{q}_{12}(s) \widetilde{q}_{21}(s)} \\
\widetilde{\varphi}_{23}(s)=\frac{\widetilde{q}_{23}(s)+\widetilde{q}_{21}(s) \widetilde{q}_{13}(s)}{1-\widetilde{q}_{12}(s) \widetilde{q}_{21}(s)}
\end{gathered}
$$

For model 1 (fig. 1) $\widetilde{q}_{23}(s)=0$. Hence

$$
\begin{gathered}
\widetilde{\varphi}_{13}(s)=\frac{\widetilde{q}_{13}(s)}{1-\widetilde{q}_{12}(s) \widetilde{q}_{21}(s)} \\
\widetilde{\varphi}_{23}(s)=\frac{\widetilde{q}_{21}(s) \widetilde{q}_{13}(s)}{1-\widetilde{q}_{12}(s) \widetilde{q}_{21}(s)}
\end{gathered}
$$

For model 2 (fig. 2) $\widetilde{q}_{13}(s)=0$ and

$$
\begin{array}{r}
\widetilde{\varphi}_{13}(s)=\frac{\widetilde{q}_{12}(s) \widetilde{q}_{23}(s)}{1-\widetilde{q}_{12}(s) \widetilde{q}_{21}(s)} \\
\widetilde{\varphi}_{23}(s)=\frac{\widetilde{q}_{23}(s)}{1-\widetilde{q}_{12}(s) \widetilde{q}_{21}(s)}
\end{array}
$$


The function $\widetilde{\varphi}_{13}(s)$ is Laplace transform of the probability density function of random variable $\Theta_{13}$ denoting time to the system damage if initial state of the operation is 1 (work). In other words, this random variable denotes time of the system operation safety. The function $\widetilde{\varphi}_{23}(s)$ is Laplace transform of the probability density function of random variable $\Theta_{23}$ that designates time to the system damage if initial state of the operation is 2 (renewal ). If an initial distribution of the operation process is vector $\mathbf{p}=\left[p_{1}, p_{2}\right]$ than time to the system damage is

$$
\Theta=p_{1} \Theta_{13}+p_{2} \Theta_{23}
$$

The function

$$
B(t)=P(\Theta>t), \quad t \geq 0
$$

is called a survival function or a safety function. A value $B(t)$ denotes probability of the system safety at an moment $t$. A Laplace transform of this function is

$$
\widetilde{B}(s)=\frac{1-\left[p_{1} \widetilde{\varphi}_{13}(s)+p_{2} \widetilde{\varphi}_{23}(s)\right]}{s}
$$

It is essentially simpler to find the expected values and the second moment of the random variables $\Theta_{i A}, i \in A^{\prime}$. If the second moments of the waiting times $T_{i}, i \in A^{\prime}$ are positive and commonly bounded, and $f_{i A}=1, \quad i \in A^{\prime}$, then the expected values of the random variables $\Theta_{i A}, i \in A^{\prime}$ are the unique solution of equation

$$
\left(I-\mathbf{P}_{A^{\prime}}\right) \overline{\boldsymbol{\Theta}}_{A^{\prime}}=\overline{\mathbf{T}}_{A^{\prime}},
$$

where

$$
\begin{array}{cc}
\mathbf{I}=\left[\delta_{i j}: i, j \in A^{\prime}\right], \quad \mathbf{P}_{A^{\prime}} & =\left[p_{i j}: i, j \in A^{\prime}\right], \\
\overline{\boldsymbol{\Theta}}_{A^{\prime}}=\left[E\left(\Theta_{i A}\right): i \in A^{\prime}\right]^{T}, & \mathbf{T}_{A^{\prime}}=\left[E\left(T_{i}\right): i \in A^{\prime}\right]^{T}
\end{array}
$$

In our case we have

$$
\mathbf{I}=\left[\begin{array}{ll}
1 & 0 \\
0 & 1
\end{array}\right], \quad \mathbf{P}_{A^{\prime}}(s)=\left[\begin{array}{cc}
0 & p_{12} \\
p_{21} & 0
\end{array}\right], \quad \overline{\boldsymbol{\Theta}}_{A^{\prime}}=\left[\begin{array}{c}
\bar{\Theta}_{13} \\
\bar{\Theta}_{23}
\end{array}\right], \quad \overline{\mathbf{T}}_{A^{\prime}}=\left[\begin{array}{c}
E\left(T_{1}\right) \\
E\left(T_{2}\right)
\end{array}\right] .
$$

The solution of the equation (41) is

$$
\begin{aligned}
& \bar{\Theta}_{13}=E\left(\Theta_{13}\right)=\frac{E\left(T_{1}\right)+p_{12} E\left(T_{2}\right)}{1-p_{12} p_{21}} \\
& \bar{\Theta}_{23}=E\left(\Theta_{23}\right)=\frac{E\left(T_{2}\right)+p_{21} E\left(T_{1}\right)}{1-p_{12} p_{21}}
\end{aligned}
$$

where

$$
E\left(T_{1}\right)=E[\min (\xi, \varsigma)], \quad E\left(T_{2}\right)=E[\min (\eta, \gamma)]
$$


and the transition probabilities $p_{12}, p_{21}$ are given by (20) and (21). According to (39), the mean time to damage of the system or time of the system operation safety is given by the formula

\section{Examples}

$$
E(\Theta)=p_{1} E\left(\Theta_{13}\right)+p_{2} E\left(\Theta_{23}\right)
$$

\section{Example 1}

We will investigate a model corresponding to a graph shown in figure 1. As we know in this case a kernel of a semi-Markov process being model of unsafety operation has form

$$
\mathbf{Q}(t)=\left[\begin{array}{ccc}
0 & Q_{12}(t) & Q_{13}(t) \\
Q_{21}(t) & 0 & 0 \\
0 & 0 & Q_{33}(t)
\end{array}\right]
$$

Now we assume that

$$
F_{\xi}(t)=\left\{\begin{array}{ll}
0 & \text { for } t<w \\
1 & \text { for } t \geq w
\end{array}, \quad F_{\eta}(t)=\left\{\begin{array}{ll}
0 & \text { for } t<r \\
1 & \text { for } t \geq r
\end{array}, \quad F_{\zeta}(t)=\left\{\begin{array}{c}
0 \text { for } t<0 \\
1-\mathrm{e}^{-\lambda t} \text { for } t \geq 0
\end{array}\right.\right.\right.
$$

It means that the duration of functioning periods are determined and they are equal to $w$ and the duration of repairing periods are determined and they are equal to $r$.

The nonnegative elements of the matrix $\mathbf{Q}(t)$ we calculate from (9), (10), (11):

$$
\begin{gathered}
Q_{12}(t)=\int_{0}^{t}\left[1-F_{\zeta}(x)\right] d F_{\xi}(x)=\left\{\begin{array}{lll}
0 & \text { for } & t<w \\
\mathrm{e}^{-\lambda \mathrm{w}} & \text { for } & t \geq w
\end{array}\right. \\
Q_{13}(t)=\int_{0}^{t}\left[1-F_{\xi}(x)\right] d F_{\zeta}(x)=\left\{\begin{array}{lll}
1-\mathrm{e}^{-\lambda \mathrm{t}} & \text { dla } & t<w \\
1-\mathrm{e}^{-\lambda \mathrm{w}} & \text { dla } & t \geq w
\end{array}\right. \\
Q_{21}(t)=F_{\eta}(t)=\left\{\begin{array}{lll}
0 & \text { dla } & t<r \\
1 & \text { dla } & t \geq r
\end{array},\right. \\
Q_{23}(t)=0 .
\end{gathered}
$$

We also suppose that the operation start from the state $S_{p}, p_{1}=1$.

Under above assumption, the transition matrix of the embedded Markov chain $\left\{X\left(\tau_{n}\right): n=0,1,2, \ldots\right\}$ is

$$
\mathbf{P}=\left[\begin{array}{ccc}
0 & p_{12} & p_{13} \\
1 & 0 & 0 \\
0 & 0 & 1
\end{array}\right],
$$


where

$$
p_{12}=\mathrm{e}^{-\lambda \mathrm{w}}, \quad p_{13}=1-\mathrm{e}^{-\lambda \mathrm{w}}
$$

The cumulative probability distributions of waiting times are:

$$
\begin{aligned}
& G_{1}(t)=Q_{12}(t)+Q_{13}(t)=\left\{\begin{array}{c}
1-\mathrm{e}^{-\lambda \mathrm{t}} \quad \text { dla } \quad t<w \\
1 \text { dla } t \geq w
\end{array},\right. \\
& G_{2}(t)=Q_{21}(t)=\left\{\begin{array}{lll}
0 & \text { dla } & t<r \\
1 & \text { dla } & t \geq r
\end{array} .\right.
\end{aligned}
$$

The expectations of waiting times are:

$$
E\left(T_{1}\right)=E[\min (w, \varsigma)]=\frac{1-\mathrm{e}^{-\lambda \mathrm{w}}}{\lambda}, \quad E\left(T_{2}\right)=r
$$

From (42) and (44) we obtain the mean time to damage or mean time of the system operation safety.

$$
E(\Theta)=\bar{\Theta}_{13}=E\left(\Theta_{13}\right)=\frac{E\left(T_{1}\right)+p_{12} E\left(T_{2}\right)}{1-p_{12} p_{21}}=\frac{\frac{1-\mathrm{e}^{-\lambda \mathrm{w}}}{\lambda}+\mathrm{e}^{-\lambda \mathrm{w}} r}{1-\mathrm{e}^{-\lambda \mathrm{w}}}
$$

For

$$
w=16[h], \quad r=8[h], \quad \lambda=0.001\left[\frac{1}{h}\right]
$$

we obtain

\section{Example 2}

$$
E(\Theta)=1496.00[h]
$$

We will consider the same semi-Markov model with a kernel

$$
\mathbf{Q}(t)=\left[\begin{array}{ccc}
0 & Q_{12}(t) & Q_{13}(t) \\
Q_{21}(t) & 0 & 0 \\
0 & 0 & Q_{33}(t)
\end{array}\right]
$$

assuming that the all random variables are exponentially distributed:

$$
\begin{array}{cc}
F_{\xi}(t)=1-\mathrm{e}^{-\alpha \mathrm{t}}, & t \geq 0, \\
F_{\eta}(t)=1-\mathrm{e}^{-\beta \mathrm{t}}, & t \geq 0, \\
F_{\zeta}(t)=1-\mathrm{e}^{-\lambda \mathrm{t}}, & t \geq 0
\end{array}
$$

The nonnegative elements of the matrix $\mathbf{Q}(t)$ for $\quad t \geq 0$ are

$$
\begin{gathered}
Q_{12}(t)=\frac{\alpha}{\lambda+\alpha}\left(1-e^{-(\lambda+\alpha) t}\right), \quad Q_{13}(t)=\frac{\lambda}{\lambda+\alpha}\left(1-e^{-(\lambda+\alpha) t}\right) \\
Q_{21}(t)=1-e^{-\beta t}
\end{gathered}
$$

We also suppose that the operation start from the state $S_{p}, p_{1}=1$. Now, the matrix of transition probabilities for the embedded Markov chain $\left\{X\left(\tau_{n}\right): n=0,1,2, \ldots\right\}$ is 


$$
\mathbf{P}=\left[\begin{array}{ccc}
0 & p_{12} & p_{13} \\
1 & 0 & 0 \\
0 & 0 & 1
\end{array}\right]
$$

where

$$
p_{12}=\frac{\alpha}{\lambda+\alpha}, \quad p_{13}=\frac{\lambda}{\lambda+\alpha}
$$

The cumulative probability distributions of waiting times are:

$$
\begin{gathered}
G_{1}(t)=Q_{12}(t)+Q_{13}(t)=1-e^{-(\lambda+\alpha) t}, \\
G_{2}(t)=Q_{21}(t)=1-e^{-\beta t}
\end{gathered}
$$

The expectations of waiting times are:

$$
E\left(T_{1}\right)=E[\min (\xi, \varsigma)]=\frac{1}{\lambda+\alpha}, \quad E\left(T_{2}\right)=\frac{1}{\beta}
$$

From (42) and (44) we obtain the mean time to damage of the system.

$$
E(\Theta)=\bar{\Theta}_{13}=E\left(\Theta_{13}\right)=\frac{E\left(T_{1}\right)+p_{12} E\left(T_{2}\right)}{1-p_{12} p_{21}}=\frac{\frac{1}{\lambda+\alpha}+\frac{\alpha}{(\lambda+\alpha) \beta}}{1-\frac{\alpha}{\lambda+\alpha}}=\frac{\alpha+\beta}{\lambda \beta}
$$

For

$$
\alpha=\frac{1}{16}\left[\frac{1}{h}\right], \quad \beta=\frac{1}{8}\left[\frac{1}{h}\right], \quad \lambda=0.001\left[\frac{1}{h}\right]
$$

we get

$$
E(\Theta)=1500.00[h]
$$

Recall that the function

$$
\widetilde{\varphi}_{13}(s)=\frac{\widetilde{q}_{13}(s)}{1-\widetilde{q}_{12}(s) \widetilde{q}_{21}(s)}
$$

is the Laplace transform of the probability density function of random variable $\Theta_{13}$ denoting time to the system damage if initial state of the operation is 1 .

In this case

$$
\begin{gathered}
\widetilde{q}_{12}(s)=\frac{\alpha}{s+\lambda+\alpha} \quad \tilde{q}_{13}(s)=\frac{\lambda}{s+\lambda+\alpha} \quad \tilde{q}_{21}(s)=\frac{\beta}{s+\beta} \\
\widetilde{\varphi}_{13}(s)=\frac{\frac{\lambda}{s+\lambda+\alpha}}{1-\frac{\alpha}{s+\lambda+\alpha} \cdot \frac{\beta}{s+\beta}}=\frac{\lambda(s+\beta)}{s^{2}+(\alpha+\beta+\lambda) s+\lambda \beta}
\end{gathered}
$$


The density function of the time to damage we get as inverse Laplace transform of $\widetilde{\varphi}_{13}(s)$. For the same parameters $\alpha, \beta, \lambda$ we obtain

$\varphi_{13}(t)=0.01\left(0.357652 \mathrm{e}^{-0.190954 \mathrm{t}}+0.0642348 \mathrm{e}^{-0.00654608 \mathrm{t}}\right), \quad t \geq 0$

The safety (survival) function of the system we obtain as inverse Laplace transform of the function

$$
\widetilde{B}(s)=\frac{1-\widetilde{\varphi}_{13}(s)}{s}
$$

In this case we obtain

$$
B(t)=0.01873 \mathrm{e}^{-0.190954 t}+0.98127 \mathrm{e}^{-0.00654608 \mathrm{t}}, \quad t \geq 0
$$

\section{Conclusions}

The semi-Markov processes theory is convenient for description of the safety and reliability systems evolution through the time. the probabilistic characteristics of semi-Markov processes are interpreted as the reliability and safety coefficients of the systems. if $a$ represents the subset of failing states or the states of damage and $i$ is an initial state, the random variable $\Theta_{i A}$ designating the first passage time from the state $i$ to the states subset $a$, denotes the time to failure of the system. theorems of semi-Markov processes theory allows us to find the reliability characteristic, like the distribution of the time to failure or the survival time, the reliability function or survival function, the mean time to failure or damage, the availability coefficient of the system and many others. we should remember that semiMarkov process may be applied as a model of the real system reliability evolution, only if the basic properties of the semi-markov process definition are satisfied by the real system.

\section{References}

[1] Броди С.М., Власенко О.Н.: Надежность систем со многими режимами работы, [в:] Теория надежности и массовое обслужсивание, Изд-во „Наука”, Москва 1969.

[2] Grabski F., Semi-Markowskie modele niezawodności i eksploatacji. IBS PAN Warszawa, 2002.

[3] Grabski F., The reliability of the object with semi-Markov failure rate. Applied Mathematics and Computation, Elsevier 2003.

[4] Grabski F., Jaźwiński J.: Metody bayesowskie w niezawodności i diagnostyce. Wydawnictw Komunikacji i Łączności, Warszawa 2001. 
[5] Jaźwiński J., Grabski F.: Niektóre problemy modelowania systemów transportowych. Instytut Technologii Eksploatacji, Radom 2003.

[6] Jaźwiński J., Ważyńska-Fiok K.: Bezpieczeństwo systemów. PWN, Warszawa 1993.

[7] Ważyńska-Fiok K., Jaźwiński J.: Niezawodność systemów technicznych. PWN, Warszawa 1990.

[8] Żurek J.: Modelowanie symboliczne systemów bezpieczeństwa i niezawodności w transporcie lotniczym. Oficyna Wydawnicza Politechniki Warszawskiej, Warszawa 1998. 


\section{SEMI-MARKOWSKIE MODELE BEZPIECZEŃSTWA EKSPLOATACJI SYSTEMÓW ODNAWIALNYCH}

\section{Opis problemu i założenia}

W wielu realnych sytuacjach długości przedziałów czasów pracy (użytkowania) oraz długości przedziałów czasów odnowy (naprawy, obsługi) systemu możemy traktować jako zmienne losowe. Proces eksploatacji systemu można opisać jako dwustanowy proces stochastyczny nazywany procesem alternatywnym. W praktyce zarówno $\mathrm{w}$ czasie pracy jak i w trakcie obsługi możne nastąpić niebezpieczne zdarzenie powodujące zakłócenie lub przerwanie procesu eksploatacji. Naszym celem jest zbudowanie stochastycznego modelu procesu eksploatacji uwzględniającego zakłócenie bezpieczeństwa systemu. Model ten pozwala znaleźć charakterystyki bezpieczeństwa i niezawodności systemu.

Zakładamy, że czasy pracy są niezależnymi kopiami nieujemnej zmiennej losowej $\xi$ o rozkładzie określonym przez dystrybuantę $F_{\xi}(\cdot)$ natomiast czasy odnowy (obsługi) są niezależnymi kopiami nieujemnej zmiennej losowej $\eta$ o dystrybuancie $F_{\eta}(\cdot)$.

Przyjmujemy następujące stany systemu:

$S_{p} \leftrightarrow 1$ - praca (użytkowanie) systemu

$S_{o} \leftrightarrow 2$ - odnowa (obsługa) systemu

$S_{B} \leftrightarrow 3$ - zagrożenie bezpieczeństwa (zdarzenie niebezpieczne, uszkodzenie)

Będziemy rozpatrywać trzy modele bezpieczeństwa procesu eksploatacji

1) System w czasie pracy może ulec uszkodzeniu. Przyjmujemy, że czas do niebezpiecznego zdarzenia liczony o chwili rozpoczęcia cyklu pracy jest nieujemną zmienną losową $\varsigma$ o rozkładzie określonym przez gęstość $f_{\eta}(\cdot)$. Niebezpieczne zdarzenie (uszkodzenie) powoduje przerwanie (zakończenie ) procesu eksploatacji. Możliwe zmiany stanów systemu przedstawione są na rysunku 1 . 


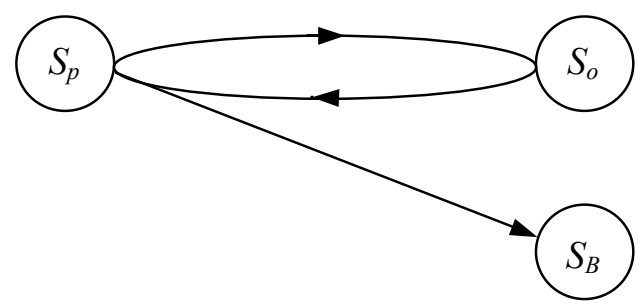

Rys. 1. Graf ilustrujący pracę systemu odnawialnego z niebezpiecznym stanem pracy.

2) System w czasie obsługi(odnowy) może ulec uszkodzeniu. Czas do niebezpiecznego zdarzenia liczony o chwili rozpoczęcia cyklu odnowy jest nieujemną zmienną losową $\gamma$ o rozkładzie określonym przez gęstość $f_{\gamma}(\cdot)$. Niebezpieczne zdarzenie powoduje przerwanie (zakończenie) procesu eksploatacji. W tym przypadku możliwe zmiany stanów systemu przedstawione są na rysunku 2.

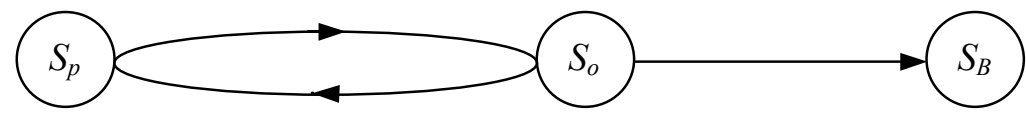

Rys. 2. Graf elementu z niebezpiecznym stanem odnowy.

3) System zarówno w czasie pracy jak i w trakcie obsługi może ulec uszkodzeniu. Przyjmujemy, że czas do niebezpiecznego zdarzenia $\mathrm{w}$ trakcie pracy jest nieujemną zmienną losową $\varsigma$ o rozkładzie określonym przez gęstość $f_{\varsigma}(\cdot)$ natomiast czas do niebezpiecznego zdarzenia $\mathrm{W}$ trakcie obsługi jest nieujemną zmienną losową $\gamma$ o rozkładzie określonym przez gęstość $f_{\gamma}(\cdot)$. Niebezpieczne zdarzenie powoduje przerwanie (zakończenie ) procesu eksploatacji. Możliwe zmiany stanów systemu przedstawione są na rysunku 3.

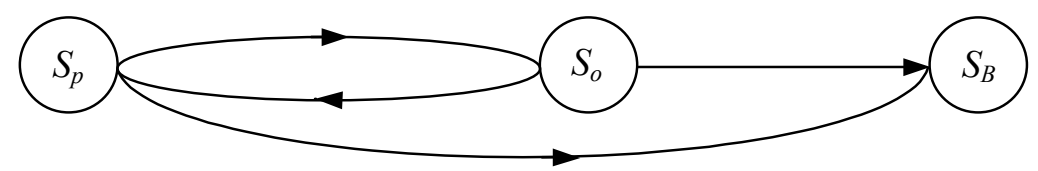

Rys. 3. Graf elementu z niebezpiecznym stanem pracy i stanem odnowy.

Przyjmujemy, że wszystkie występujące zmienne losowe są wzajemnie niezależne. 


\section{Model}

Chcąc znaleźć charakterystyki bezpieczeństwa i niezawodności systemu skonstruujemy model procesu eksploatacji systemu $\mathrm{Z}$ zakłóceniami bezpieczeństwa. Przy przyjętych założeniach naturalnym modelem może być proces semi-markowski

$\{X(t): t \geq 0\}$ o zbiorze stanów $S=\{1,2,3\} \equiv\left\{S_{p}, S_{o}, S_{B}\right\}$. Chcąc zbudować semimarkowski model musimy zdefiniować niezerowe elementy jądra

$$
\begin{gathered}
\mathbf{Q}(t)=\left[Q_{i j}(t): i, j \in S\right] \\
Q_{i j}(t)=P\left\{X\left(\tau_{n+1}\right)=j, \tau_{n+1}-\tau_{n} \leq t \mid X\left(\tau_{n}\right)=i\right\}
\end{gathered}
$$

Zbudujemy model najbardziej ogólny odpowiadający grafowi zmian stanów przedstawionemu na rysunku 3. Jądro procesu ma w tym przypadku postać

$$
\mathbf{Q}(t)=\left[\begin{array}{ccc}
0 & Q_{12}(t) & Q_{13}(t) \\
Q_{21}(t) & 0 & Q_{23}(t) \\
0 & 0 & Q_{33}(t)
\end{array}\right],
$$

Na podstawie założeń otrzymujemy

$$
\begin{gathered}
Q_{12}(t)=P\{\xi \leq t, \varsigma>\xi\}=\int_{0}^{t}\left[1-F_{\zeta}(x)\right] d F_{\xi}(x), \\
Q_{13}(t)=P\{\zeta \leq t, \varsigma<\xi\}=\int_{0}^{t}\left[1-F_{\xi}(x)\right] d F_{\zeta}(x), \\
Q_{21}(t)=P\{\eta \leq t, \gamma>\eta\}=\int_{0}^{t}\left[1-F_{\gamma}(x)\right] d F_{\eta}(x), \\
Q_{23}(t)=P\{\gamma \leq t, \gamma<\eta\}=\int_{0}^{t}\left[1-F_{\eta}(x)\right] d F_{\gamma}(x), \\
Q_{33}(t)=H(t) .
\end{gathered}
$$

Przez podstawienie

$$
F_{\gamma}(x)=\left\{\begin{array}{lll}
0 & \text { for } & \mathrm{x}<\infty \\
1 & \text { for } & \mathrm{x}=\infty
\end{array}\right.
$$

otrzymujemy model odpowiadający grafowi przedstawionemu na rys. 1 .

Mamy

$$
\begin{array}{r}
Q_{12}(t)=\int_{0}^{t}\left[1-F_{\zeta}(x)\right] d F_{\xi}(x), \\
Q_{13}(t)=\int_{0}^{t}\left[1-F_{\xi}(x)\right] d F_{\zeta}(x),
\end{array}
$$




$$
\begin{aligned}
& Q_{21}(t)=F_{\eta}(t), \\
& Q_{23}(t)=0,
\end{aligned}
$$

Model, który odpowiada rysunkowi 2 , otrzymujemy podstawiając

$$
F_{\varsigma}(x)=\left\{\begin{array}{lll}
0 & \text { for } & \mathrm{x}<\infty \\
1 & \text { for } & \mathrm{x}=\infty
\end{array}\right.
$$

W tym przypadku elementy semi-markowskiego jądra mają postać

$$
\begin{gathered}
Q_{12}(t)=F_{\xi}(t), \\
Q_{13}(t)=0, \\
Q_{21}(t)=P\{\eta \leq t, \gamma>\eta\}=\int_{0}^{t}\left[1-F_{\gamma}(x)\right] d F_{\eta}(x), \\
Q_{23}(t)=P\{\gamma \leq t, \gamma<\eta\}=\int_{0}^{t}\left[1-F_{\eta}(x)\right] d F_{\gamma}(x) .
\end{gathered}
$$

\section{Charakterystyki bezpieczeństwa i niezawodności}

Z definicji procesu semi-markowskiego [2], [3] , [5] wynika , że ciąg zmiennych losowych $\left\{X\left(\tau_{n}\right): n=0,1,2, \ldots\right\}$, gdzie $\tau_{n} ; n=0,1,2, .$. są chwilami zmian stanów jest łańcuchem Markowa o macierzy prawdopodobieństw przejść

$$
\mathbf{P}=\left[p_{i j}: i, j \in S\right], \quad p_{i j}=P\left\{X\left(\tau_{n+1}\right)=j \mid X\left(\tau_{n}\right)=i\right\}=\lim _{t \rightarrow \infty} Q_{i j}(t)
$$

Ciagg $\left\{X\left(\tau_{n}\right): n=0,1,2, \ldots\right\}$ nazywany jest łańcuchem Markowa włożonym $\mathrm{W}$ proces semi-markowski $\{X(t): t \geq 0\}$. W naszym ogólnym modelu macierz $\mathbf{P}$ ma postać

$$
\mathbf{P}=\left[\begin{array}{ccc}
0 & p_{12} & p_{13} \\
p_{21} & 0 & p_{23} \\
0 & 0 & 1
\end{array}\right],
$$

gdzie

$$
\begin{gathered}
p_{12}=P\{\varsigma>\xi\}=\int_{0}^{\infty}\left[1-F_{\varsigma}(x)\right] d F_{\xi}(x), \\
p_{13}=P\{\varsigma<\xi\}=\int_{0}^{\infty}\left[1-F_{\xi}(x)\right] d F_{\zeta}(x)=1-p_{12}, \\
p_{21}=P\{\gamma>\eta\}=\int_{0}^{\infty}\left[1-F_{\gamma}(x)\right] d F_{\eta}(x), \\
p_{23}(t)=P\{\gamma<\eta\}=\int_{0}^{\infty}\left[1-F_{\eta}(x)\right] d F_{\gamma}(x)=1-p_{21},
\end{gathered}
$$


Realizacje procesu semi-markowskiego są funkcjami przyjmującymi stałe wartości w przedziałach $\left[\tau_{n}, \tau_{n+1}\right)$ i są one prawostronnie ciagłe.

Funkcja

$$
F_{i j}(t)=P\left\{\tau_{n+1}-\tau_{n} \leq t \mid X\left(\tau_{n}\right)=i, X\left(\tau_{n+1}\right)=j\right\}=\frac{Q_{i j}(t)}{p_{i j}}
$$

jest dystrybuantą zmiennej losowej $T_{i j}$ oznaczającej czas trwania stanu $i$, gdy następnym stanem będzie stan $j$. Ze wzoru (24) mamy

$$
Q_{i j}(t)=p_{i j} F_{i j}(t) .
$$

Funkcja

$$
G_{i}(t)=P\left\{\tau_{n+1}-\tau_{n} \leq t \mid X\left(\tau_{n}\right)=i\right\}=\sum_{j \in S} Q_{i j}(t)
$$

jest dystrybuantą rozkładu zmiennej losowej $T_{i}$ oznaczającej czas trwania stanu $i$.Zmienna losowa $T_{i}$ czas trwania stanu $i$ bez względu na następny stan. W naszym modelu

$$
G_{1}(t)=Q_{12}(t)+Q_{13}(t), \quad G_{2}(t)=Q_{21}(t)+Q_{23}(t), \quad G_{3}(t)=Q_{33}(t)
$$

Bardzo ważną charakterystyką procesu semi-Markowskiego jest czas pierwszego przejścia ze stanu i do podzbioru A.

Zmienna losowa

$$
\Theta_{A}=\tau_{\Delta_{A}},
$$

gdzie

$$
\Delta_{A}=\min \left\{n \in N: X\left(\tau_{n}\right) \in A\right\},
$$

oznacza chwilę pierwszego przybycia procesu semi-Markowa do zbioru stanów $A$.

Funkcja

$$
\Phi_{i A}(t)=P\left\{\Theta_{A} \leq t \mid X(0)=i\right\}
$$

jest dystrybuantą rozkładu zmiennej losowej $\Theta_{i A}$ oznaczającej czas pierwszego przejścia ze stanu $i$ do podzbioru stanów $A$.

\section{Twierdzenie [2]}

Dla regularnego procesu semi-Markowa i takiego, że

$$
f_{i A}=P\left\{\Delta_{A}<\infty \mid X(0)=i\right\}=1, \quad i \in A^{\prime},
$$

dystrybuanty $\Phi_{i A}(t), \quad i \in A^{\prime} \quad$ sq jedynymi rozwiqzaniami układu równań calkowych

$$
\Phi_{i A}(t)=\sum_{j \in A} Q_{i j}(t)+\sum_{k \in S_{0}}^{t} \int_{k A}(t-x) d Q_{i k}(x), i \in A^{\prime}
$$


Stosując przekształcenie Laplace-Stieltjesa otrzymujemy układ równań liniowych

$$
\widetilde{\phi}_{i A}(s)=\sum_{j \in A} \widetilde{q}_{i j}(s)+\sum_{k \in A^{\prime}} \widetilde{\phi}_{k A}(s) \widetilde{q}_{i k}(s), i \in A^{\prime},
$$

gdzie niewiadomymi są transformaty

$$
\widetilde{\phi}_{i A}(s)=\int_{0}^{\infty} e^{-s t} d \Phi_{i A}(t) .
$$

Ten układ równań w zapisie macierzowym ma postać

$$
\left(I-\widetilde{\mathbf{q}}_{A^{\prime}}(s)\right) \widetilde{\boldsymbol{\varphi}}_{A^{\prime}}(s)=\widetilde{\mathbf{b}}(s),
$$

gdzie

$$
\begin{gathered}
\mathbf{I}=\left[\delta_{i j}: i, j \in A^{\prime}\right], \quad \widetilde{\mathbf{q}}_{A^{\prime}}(s)=\left[\widetilde{q}_{i j}(s): i, j \in A\right] \\
\widetilde{q}_{i j}(s)=\int_{0}^{\infty} e^{-s t} d Q_{i j}(t)
\end{gathered}
$$

są macierzami kwadratowymi, natomiast

$$
\widetilde{\boldsymbol{\varphi}}_{A^{\prime}}(s)=\left[\widetilde{\varphi}_{i A}(s): i \in A^{\prime}\right]^{T}, \quad \widetilde{\mathbf{b}}(s)=\left[\sum_{j \in A} \widetilde{q}_{i j}(s): i \in A^{\prime}\right]^{T}
$$

są jednokolumnowymi macierzami transformat

W rozpatrywanym modelu mamy: $A^{\prime}=\{1,2\}, A=\{3\}$,

$$
\mathbf{I}=\left[\begin{array}{ll}
1 & 0 \\
0 & 1
\end{array}\right], \quad \widetilde{\mathbf{q}}_{A^{\prime}}(s)=\left[\begin{array}{cc}
0 & \widetilde{q}_{12}(s) \\
\widetilde{q}_{21}(s) & 0
\end{array}\right], \quad \widetilde{\boldsymbol{\varphi}}_{A^{\prime}}(s)=\left[\begin{array}{l}
\widetilde{\varphi}_{13}(s) \\
\widetilde{\varphi}_{23}(s)
\end{array}\right], \quad \widetilde{\mathbf{b}}(s)=\left[\begin{array}{c}
\widetilde{q}_{13}(s) \\
\widetilde{q}_{23}(s)
\end{array}\right] .
$$

W tym przypadku rozwiązanie równania (32) ma postać

$$
\begin{gathered}
\widetilde{\varphi}_{13}(s)=\frac{\widetilde{q}_{13}(s)+\widetilde{q}_{12}(s) \widetilde{q}_{23}(s)}{1-\widetilde{q}_{12}(s) \widetilde{q}_{21}(s)} \\
\widetilde{\varphi}_{23}(s)=\frac{\widetilde{q}_{23}(s)+\widetilde{q}_{21}(s) \widetilde{q}_{13}(s)}{1-\widetilde{q}_{12}(s) \widetilde{q}_{21}(s)}
\end{gathered}
$$

W szczególności dla model 1 (rysunek 1) $\widetilde{q}_{23}(s)=0$. Stąd

$$
\begin{aligned}
\widetilde{\varphi}_{13}(s) & =\frac{\widetilde{q}_{13}(s)}{1-\widetilde{q}_{12}(s) \widetilde{q}_{21}(s)} \\
\widetilde{\varphi}_{23}(s) & =\frac{\widetilde{q}_{21}(s) \widetilde{q}_{13}(s)}{1-\widetilde{q}_{12}(s) \widetilde{q}_{21}(s)}
\end{aligned}
$$

Dla modelu 2 (rysunek 2) $\widetilde{q}_{13}(s)=0$ oraz

$$
\begin{gathered}
\widetilde{\varphi}_{13}(s)=\frac{\widetilde{q}_{12}(s) \widetilde{q}_{23}(s)}{1-\widetilde{q}_{12}(s) \widetilde{q}_{21}(s)} \\
\widetilde{\varphi}_{23}(s)=\frac{\widetilde{q}_{23}(s)}{1-\widetilde{q}_{12}(s) \widetilde{q}_{21}(s)}
\end{gathered}
$$


Funkcja $\widetilde{\varphi}_{13}(s)$ jest transformatą Laplace'a gęstości rozkładu zmiennej losowej $\Theta_{13}$ oznaczającej czas do chwili zajścia zdarzenia niebezpiecznego w procesie eksploatacji pod warunkiem, że stanem początkowym był stan 1 (praca). Można również powiedzieć, że ta zmienna losowa oznacza czas bezpiecznej eksploatacji systemu. Funkcja $\widetilde{\varphi}_{23}(s)$ jest transformata Laplace'a gęstości rozkładu zmiennej losowej $\Theta_{23}$ oznaczającej czas do chwili zajścia zdarzenia niebezpiecznego $\mathrm{w}$ procesie eksploatacji pod warunkiem, że stanem początkowym był stan 2 (odnowa).

Jeżeli rozkładem początkowym procesu eksploatacji jest wektor $\mathbf{p}=\left[p_{1}, p_{2}\right]$ to zmienna losowa

$$
\Theta=p_{1} \Theta_{13}+p_{2} \Theta_{23}
$$

oznacza czas bezpiecznej eksploatacji albo czas upływający do chwili zajścia zdarzenia niebezpiecznego.

Funkcja

$$
B(t)=P(\Theta>t), \quad t \geq 0
$$

nosi nazwę funkcji "przeżycia" albo funkcji bezpieczeństwa. Liczba $B(t)$ oznacza prawdopodobieństwo bezpieczeństwa systemu $\mathrm{W}$ chwili $t$. Transformata Laplace'a tej funkcji ma postać

$$
\widetilde{B}(s)=\frac{1-\left[p_{1} \widetilde{\varphi}_{13}(s)+p_{2} \widetilde{\varphi}_{23}(s)\right]}{s} .
$$

Znacznie łatwiej można znaleźć wartość oczekiwaną rozkładu zmiennych losowych $\Theta_{i A}, i \in A^{\prime}$. Jeżeli wartość oczekiwane zmiennych losowych $T_{i}, i \in A^{\prime}$ są dodatnie I wspólnie ograniczone oraz $f_{i A}=1, \quad i \in A^{\prime}$, to wartości oczekiwane zmiennych losowych $\Theta_{i A}, i \in A^{\prime}$ są rozwiązaniami równania

$$
\left(I-\mathbf{P}_{A^{\prime}}\right) \overline{\boldsymbol{\Theta}}_{A^{\prime}}=\overline{\mathbf{T}}_{A^{\prime}},
$$

gdzie

$$
\begin{array}{cc}
\mathbf{I}=\left[\delta_{i j}: i, j \in A^{\prime}\right], \quad \mathbf{P}_{A^{\prime}} & =\left[p_{i j}: i, j \in A^{\prime}\right], \\
\overline{\boldsymbol{\Theta}}_{A^{\prime}}=\left[E\left(\Theta_{i A}\right): i \in A^{\prime}\right]^{T}, & \mathbf{T}_{A^{\prime}}=\left[E\left(T_{i}\right): i \in A^{\prime}\right]^{T}
\end{array}
$$

W naszym przypadku

$$
\mathbf{I}=\left[\begin{array}{ll}
1 & 0 \\
0 & 1
\end{array}\right], \quad \mathbf{P}_{A^{\prime}}(s)=\left[\begin{array}{cc}
0 & p_{12} \\
p_{21} & 0
\end{array}\right], \quad \overline{\boldsymbol{\Theta}}_{A^{\prime}}=\left[\begin{array}{c}
\bar{\Theta}_{13} \\
\bar{\Theta}_{23}
\end{array}\right], \quad \overline{\mathbf{T}}_{A^{\prime}}=\left[\begin{array}{c}
E\left(T_{1}\right) \\
E\left(T_{2}\right)
\end{array}\right] .
$$

Rozwiązanie równania (41) ma postać

$$
\begin{aligned}
& \bar{\Theta}_{13}=E\left(\Theta_{13}\right)=\frac{E\left(T_{1}\right)+p_{12} E\left(T_{2}\right)}{1-p_{12} p_{21}} \\
& \bar{\Theta}_{23}=E\left(\Theta_{23}\right)=\frac{E\left(T_{2}\right)+p_{21} E\left(T_{1}\right)}{1-p_{12} p_{21}}
\end{aligned}
$$


gdzie

$$
E\left(T_{1}\right)=E[\min (\xi, \varsigma)], \quad E\left(T_{2}\right)=E[\min (\eta, \gamma)]
$$

natomiast prawdopodobieństwa $p_{12}, \quad p_{21}$ dane są wzorami (20) i (21). Na podstawie (39), oczekiwany czas bezpieczeństwa systemu w procesie eksploatacji jest okreslony wzorem

$$
E(\Theta)=p_{1} E\left(\Theta_{13}\right)+p_{2} E\left(\Theta_{23}\right)
$$

\section{Przyklady}

\section{Przykład 1.}

Będziemy badać model 1, odpowiadający grafowi na rysunku 1. Jak wiemy w tym przypadku proces semi-Markowa będący modelem niebezpiecznego procesu eksploatacji określony jest przez jądro postaci

$$
\mathbf{Q}(t)=\left[\begin{array}{ccc}
0 & Q_{12}(t) & Q_{13}(t) \\
Q_{21}(t) & 0 & 0 \\
0 & 0 & Q_{33}(t)
\end{array}\right]
$$

Zakładamy, że

$$
F_{\xi}(t)=\left\{\begin{array}{lll}
0 & \text { dla } & t<w \\
1 & \text { dla } & t \geq w
\end{array}, \quad F_{\eta}(t)=\left\{\begin{array}{lll}
0 & \text { dla } & t<r \\
1 & \text { dla } & t \geq r
\end{array}, \quad F_{\zeta}(t)=\left\{\begin{array}{ccc}
0 \text { dla } & t<0 \\
1-\mathrm{e}^{-\lambda t} \text { dla } & t \geq 0
\end{array}\right.\right.\right.
$$

To oznacza, że długości przedziałów czasów pracy systemu oraz długości przedziałów czasów obsługi (odnowy) są zdeterminowane i wynoszą $w$ oraz $r$ odpowiednio.

Niezerowe elementy macierzy $\mathbf{Q}(t)$ we obliczmy korzystając ze wzorów (9), (10), (11):

$$
\begin{gathered}
Q_{12}(t)=\int_{0}^{t}\left[1-F_{\zeta}(x)\right] d F_{\xi}(x)=\left\{\begin{array}{lll}
0 & \text { for } t<w \\
\mathrm{e}^{-\lambda \mathrm{w}} & \text { for } & t \geq w
\end{array},\right. \\
Q_{13}(t)=\int_{0}^{t}\left[1-F_{\xi}(x)\right] d F_{\zeta}(x)=\left\{\begin{array}{lll}
1-\mathrm{e}^{-\lambda \mathrm{t}} & \text { dla } & t<w \\
1-\mathrm{e}^{-\lambda \mathrm{w}} & \text { dla } & t \geq w
\end{array}\right. \\
Q_{21}(t)=F_{\eta}(t)=\left\{\begin{array}{lll}
0 & \text { dla } & t<r \\
1 & \text { dla } & t \geq r
\end{array}\right. \\
Q_{23}(t)=0 .
\end{gathered}
$$

Przyjmujemy również założenie że stanem początkowym procesu jest $S_{p}$, $p_{1}=1$.

Przy tych założeniach macierz prawdopodobieństw przejść włożonego łańcucha Markowa $\quad\left\{X\left(\tau_{n}\right): n=0,1,2, \ldots\right\}$ ma postać 


$$
\mathbf{P}=\left[\begin{array}{ccc}
0 & p_{12} & p_{13} \\
1 & 0 & 0 \\
0 & 0 & 1
\end{array}\right]
$$

gdzie

$$
p_{12}=\mathrm{e}^{-\lambda \mathrm{w}}, \quad p_{13}=1-\mathrm{e}^{-\lambda \mathrm{w}}
$$

Dystrybuanty czasów trwania stanów wyrażają się wzorami:

$$
\begin{aligned}
& G_{1}(t)=Q_{12}(t)+Q_{13}(t)=\left\{\begin{array}{c}
1-\mathrm{e}^{-\lambda \mathrm{t}} \text { dla } t<w \\
1 \text { dla } t \geq w
\end{array},\right. \\
& G_{2}(t)=Q_{21}(t)=\left\{\begin{array}{lll}
0 & \text { dla } & t<r \\
1 & \text { dla } & t \geq r
\end{array} .\right.
\end{aligned}
$$

Wartości oczekiwane wynoszą

$$
E\left(T_{1}\right)=E[\min (w, \varsigma)]=\frac{1-\mathrm{e}^{-\lambda \mathrm{w}}}{\lambda}, \quad E\left(T_{2}\right)=r
$$

Na podstawie wzorów (42) i (44) otrzymujemy wartość oczekiwaną czasu bezpiecznej eksploatacji systemu.

$$
E(\Theta)=\bar{\Theta}_{13}=E\left(\Theta_{13}\right)=\frac{E\left(T_{1}\right)+p_{12} E\left(T_{2}\right)}{1-p_{12} p_{21}}=\frac{\frac{1-\mathrm{e}^{-\lambda \mathrm{w}}}{\lambda}+\mathrm{e}^{-\lambda \mathrm{w}} r}{1-\mathrm{e}^{-\lambda \mathrm{w}}}
$$

Dla

$$
w=16[h], \quad r=8[h], \quad \lambda=0.001\left[\frac{1}{h}\right]
$$

obliczamy

\section{Przykład 2}

$$
E(\Theta)=1496.00[h]
$$

Rozważymy ten semi-markowski model o jądrze

$$
\mathbf{Q}(t)=\left[\begin{array}{ccc}
0 & Q_{12}(t) & Q_{13}(t) \\
Q_{21}(t) & 0 & 0 \\
0 & 0 & Q_{33}(t)
\end{array}\right]
$$

zakładając, że występujące w opisie zmienne losowe mają rozkłady wykładnicze:

$$
\begin{aligned}
& F_{\xi}(t)=1-\mathrm{e}^{-\alpha \mathrm{t}}, \quad t \geq 0, \\
& F_{\eta}(t)=1-\mathrm{e}^{-\beta \mathrm{t}}, \quad t \geq 0, \\
& F_{\zeta}(t)=1-\mathrm{e}^{-\lambda \mathrm{t}}, \quad t \geq 0
\end{aligned}
$$

Niezerowe elementy macierzy $\mathbf{Q}(t)$ dla $t \geq 0$ mają postać

$$
\begin{gathered}
Q_{12}(t)=\frac{\alpha}{\lambda+\alpha}\left(1-e^{-(\lambda+\alpha) t}\right), \quad Q_{13}(t)=\frac{\lambda}{\lambda+\alpha}\left(1-e^{-(\lambda+\alpha) t}\right) \\
Q_{21}(t)=1-e^{-\beta t}
\end{gathered}
$$


Jak poprzedni zakładamy, że proces eksploatacji startuje ze stanu $S_{p}, \quad p_{1}=1$. W tym przypadku macierz prawdopodobieństw przejść włożonego łańcucha Markowa $\left\{X\left(\tau_{n}\right): n=0,1,2, \ldots\right\}$ ma postać

$$
\mathbf{P}=\left[\begin{array}{ccc}
0 & p_{12} & p_{13} \\
1 & 0 & 0 \\
0 & 0 & 1
\end{array}\right]
$$

gdzie

$$
p_{12}=\frac{\alpha}{\lambda+\alpha}, \quad p_{13}=\frac{\lambda}{\lambda+\alpha}
$$

Dystrybuanty rozkładów czasów trwania stanów wyrażają się wzorami:

$$
\begin{gathered}
G_{1}(t)=Q_{12}(t)+Q_{13}(t)=1-e^{-(\lambda+\alpha) t}, \\
G_{2}(t)=Q_{21}(t)=1-e^{-\beta t}
\end{gathered}
$$

Wartości oczekiwane tych zmiennych losowych wynoszą:

$$
E\left(T_{1}\right)=E[\min (\xi, \varsigma)]=\frac{1}{\lambda+\alpha}, \quad E\left(T_{2}\right)=\frac{1}{\beta}
$$

$\mathrm{Na}$ podstawie (42) i (44) otrzymujemy oczekiwany czas bezpiecznej eksploatacji sytemu.

$$
E(\Theta)=\bar{\Theta}_{13}=E\left(\Theta_{13}\right)=\frac{E\left(T_{1}\right)+p_{12} E\left(T_{2}\right)}{1-p_{12} p_{21}}=\frac{\frac{1}{\lambda+\alpha}+\frac{\alpha}{(\lambda+\alpha) \beta}}{1-\frac{\alpha}{\lambda+\alpha}}=\frac{\alpha+\beta}{\lambda \beta}
$$

Dla

$$
\alpha=\frac{1}{16}\left[\frac{1}{h}\right], \quad \beta=\frac{1}{8}\left[\frac{1}{h}\right], \quad \lambda=0.001\left[\frac{1}{h}\right]
$$

obliczamy

$$
E(\Theta)=1500.00[h]
$$

Przypomnijmy, że funkcja

$$
\widetilde{\varphi}_{13}(s)=\frac{\widetilde{q}_{13}(s)}{1-\widetilde{q}_{12}(s) \widetilde{q}_{21}(s)}
$$

jest transformatą Laplace'a gęstości rozkładu zmiennej losowej $\Theta_{13}$ oznaczającej czas bezpiecznej eksploatacji sytemu, gdy stanem początkowym jest 1 . W tym przypadku

$$
\begin{gathered}
\widetilde{q}_{12}(s)=\frac{\alpha}{s+\lambda+\alpha} \quad \widetilde{q}_{13}(s)=\frac{\lambda}{s+\lambda+\alpha} \quad \widetilde{q}_{21}(s)=\frac{\beta}{s+\beta} \\
\widetilde{\varphi}_{13}(s)=\frac{\frac{\lambda}{s+\lambda+\alpha}}{1-\frac{\alpha}{s+\lambda+\alpha} \cdot \frac{\beta}{s+\beta}}=\frac{\lambda(s+\beta)}{s^{2}+(\alpha+\beta+\lambda) s+\lambda \beta}
\end{gathered}
$$

Gęstość rozkładu czasu bezpiecznej eksploatacji sytemu otrzymamy jako transformatę odwrotną . 
Dla tych samych wartości liczbowych parametrów $\alpha, \beta, \lambda$ otrzymujemy

$$
\varphi_{13}(t)=0.01\left(0.357652 \mathrm{e}^{-0.190954 \mathrm{t}}+0.0642348 \mathrm{e}^{-0.00654608 \mathrm{t}}\right), \quad t \geq 0
$$

Funkcję bezpieczeństwa systemu uzyskamy jako transformatę odwrotną funkcji

$$
\widetilde{B}(s)=\frac{1-\widetilde{\varphi}_{13}(s)}{s}
$$

W rozważanym tu przypadku otrzymujemy

$$
B(t)=0.01873 \mathrm{e}^{-0.190954 \mathrm{t}}+0.98127 \mathrm{e}^{-0.00654608 \mathrm{t}}, \quad t \geq 0
$$

\section{Wnioski}

Teoria procesów semi-Markowa jest wygodna i przydatna do opisu i analizy matematycznej bezpieczeństwa i niezawodności systemów funkcjonujących losowo w czasie. Charakterystyki procesów semimarkowskich są interpretowane jako charakterystyki bezpieczeństwa procesów eksploatacji systemów. Czas do chwili zajścia zdarzenia niebezpiecznego, gdy stanem początkowym jest stan $i$, jest zmienną losową $\Theta_{i A}$ oznaczającą czas pierwszego przejścia procesu semi-markowa ze stanu $i$ do podzbioru stanów $a$. Teoria procesów semi-markowskich pozwala znaleźć rozkład tej zmiennej losowej oraz jej parametry. Konstruując modele semi-markowskie należy pamiętać że proces semi-markowa może stanowić przybliżony model funkcjonowania systemu tylko wtedy, gdy założenia wynikające $\mathrm{z}$ definicji i własności procesu semi-markowa są spełnione przez rzeczywisty systemy.
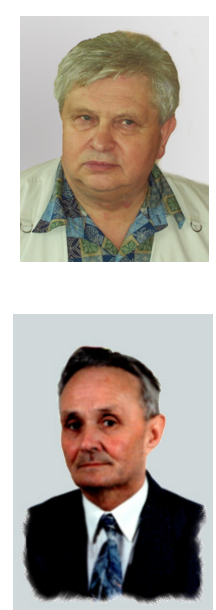

Professor Franciszek Grabski (born in 1946, Dormgen) holds the chair of mathematics and physics at the Polish Naval Academy in Gdynia. The main line of his scientific interests includes the mathematical theory of reliability. He has employed himself in the formulation and investigation into stochastic models of systems reliability and operation, and Bayesian methods in reliability. The author of nearly a hundred of scientific works, he is also the author and co-author (most often with Professor Jerzy Jaźwiński) of several manuals and five monographs.

Professor Jerzy Jaźwiński (born in1927, Torczyn). Scientific Worker of Air Force Institute of Technology. Field of science: aviation transport, reliability, safety. Author and co-author of over 200 publications and books. Co-organizer of conferences: "Reliability in transport", "Safety of the systems", "Safety and Reliability KONBiN", "Annual winter schools on reliability". Activity in the following organizations: Polish Cybernetics Society, Committee of Transport of Polish Academy of Sciences, Committee of Mashine Building of Polish Academy of Sciences, Team of Reliability of the Section of Exploitation of the Committee of Mashine Building (Polish Academy of Sciences), Committee of Scientific Investigations - Team of Transport, Society of Reliability and Safety. 